\title{
The Roles of Government Funding in Enhancing the Competitiveness of Small and Medium-sized Enterprise in Sabah, Malaysia
}

\author{
Abdol Samad Nawi ${ }^{1}$, Irwan Bin Ismail ${ }^{1}$, Zainuddin Zakaria ${ }^{1}$, Jannah Munirah Md Noor ${ }^{1}$, Bashir Ahmad Bin \\ Shabir Ahmad ${ }^{1}$, Nik Fakrul Hazri ${ }^{1}$, Wan Anisabanum Salleh ${ }^{1}$, Mohd Tajul Hasnan Mohd Tajuddin ${ }^{2} \&$ Nur \\ Raihana Mohd Sallem ${ }^{2}$ \\ ${ }^{1}$ Business \& Management Faculty, Universiti Teknologi MARA (UiTM), Dungun, Malaysia \\ ${ }^{2}$ Faculty of Accountancy, Universiti Teknologi MARA (UiTM), Dungun, Malaysia \\ Correspondence: Abdol Samad Nawi, Business \& Management Faculty, Universiti Teknologi MARA (UiTM), \\ Dungun Campus, 23000 Dungun, Malaysia. Tel: 60-9-840-0101/60-17-386-3537. E-mail: \\ samad252@tganu.uitm.edu.my
}

Received: August 15, 2012 Accepted: September 5, 2012 Online Published: November 30, 2012

doi:10.5539/ass.v8n15p24

URL: http://dx.doi.org/10.5539/ass.v8n15p24

\begin{abstract}
This study was conducted in order to determine the roles of government funding in enhancing Small and Medium-Sized Enterprises in Sabah, Malaysia. Specifically, the study is focused on the Small and Medium-Sized Enterprises in Sabah, Malaysia which were funded by many government-linked agencies such as Yayasan Tekun Nasional, Amanah Ikhtiar, Koperasi Pembangunan Desa and Agro Bank. This qualitative study was carried out in the rural and urban areas in Sabah, Malaysia. The findings of this study revealed that there are several main roles of government funding to enhance the competitiveness of Small and Medium-Sized Enterprises in Sabah, Malaysia. These four main roles were namely provision of access to capital for opening and improving the business, provision of access to capital for skills and knowledge development, improvement of entrepreneurs' relations, and promoting entrepreneurship and reducing "fear of failure". In accordance, it can be concluded that the government funds are instrumental in the success of the efforts to enhance the competitiveness level of the so-called Small and Medium-Sized Enterprises in Sabah, Malaysia. Besides, it is highly recommended that state government and all parties (the stakeholders) should specifically implement efforts to fund the Small and Medium-Sized Enterprises as well as to improve their level of competitiveness.
\end{abstract}

Keywords: small and medium enterprises, government funding

\section{Introduction}

Success in reducing the poverty among the people in any country is generally made possible by the rapid economic growth enjoyed by the nation (Yaakub, 1991). One of the platforms to improve the economic growth in any country is through the introduction of Small and Medium-Sized Enterprises. It is likely that there exists a positive correlation between reduction in poverty profile, economic growth, the presence of Small and Medium-Sized Enterprise and the provision of government's funds. Thus, this interesting relationship must be seen as a major factor that needs to be determined by the state government as an effort to ensure that it's funds be awarded to the parties that would later contribute into the economic growth of the nation. It means that the government funding of economic growth efforts must be intensified by the state government. It must be viewed essentially as the main effort to eradicate poverty.

Moreover, the funds which are provided by the state government, nowadays should be increased as it is likely to be much needed especially in the rural areas. The existence of governments' funds for Small and Medium-Sized Enterprises in Sabah has been widespread, particularly in semi-traditional enterprises such as gong making and bread making activities. Therefore, the increase in the numbers of governments' funds in this state can be the landmark of its marvelous roles towards the improvement in Small and Medium-Sized Enterprises competitiveness level. Specifically, Sabah state government and the federal government have actively promoted funds assistance to the Small and Medium-Sized Enterprises in Sabah.

These efforts have generally stimulated the process of an improvement in the competitiveness level of Small and Medium-Sizes Enterprises in Sabah. However, we never know how this effort has improved the Small and 
Medium-Sizes Enterprises level of competitiveness. There is no specific study made done on this so far. Yet we do not have specific information on this. Whereas, we, the researchers, believe that the roles of government funding towards the Small and Medium-Sized Enterprises in Sabah, if not checked properly and immediate action taken will lead to wastage of resources by the state. These problems then would bring about rapid increase in the state financial problems and later lead to the increase in the level of poverty in the state. Besides that increase in the state financial problems will lead to further political instability in this multiracial state.

In accordance, this study aimed to examine the impact of the government funds towards the improvement in the Small and Medium-Sized Enterprises in Sabah, Malaysia. Specifically, this study would concentrate on the roles of government's funding in enhancing the competitiveness of Small and Medium-Sized Enterprise which are located in neither urban nor rural areas of Sabah, Malaysia. Whether the government's funds significantly improve the Small and Medium-Sized Enterprises' competitiveness level is the focal point. Moreover, we specifically suggest that the role of government's funding in enhancing the competitiveness of Small and Medium-Sized Enterprise in this state (Sabah) is vital and this information is needed by many parties to take the necessary action.

\section{An Overview of Small and Medium-sized Enterprises in Sabah, Malaysia}

Generally, Small and Medium-Sized Enterprises or SMEs, are socially and economically important and they provide million of jobs. It is normally privately owned and operated with a smaller number of employees. Moreover, in many countries, Small and Medium-Sized Enterprises or SMEs are much greater in number than large companies and likely to be responsible for driving innovation and competition in many economic sectors. However, recently, many researchers concluded that Small and Medium-Sized Enterprises were being less competitive than large companies due to the ties with the dependence and familiarity to neighbor communities.

In Malaysia, Small and Medium-Sized Enterprises is a vital component of the country's economic development and it is a big contributor to the total manufacturing sector's output (SMIDEC, 2002 in Ali \& Nelson, 2006). Besides that, Ali \& Nelson (2006) stated that the Malaysian Government's commitment to, and concern for, the development of Small and Medium-Sizes Enterprises has been clearly evident since the early 1970s when the 'New Economic Policy' was introduced in 1971, which aimed to improve people's welfare and restructure ethnic economic imbalances. Moreover, Ali \& Nelson (2006) also stated that the government's commitment to the development of SMEs can also be seen in the second Industrial Master Plan (IMP2), which ended in 2005, which is followed by the Third Industrial Mater Plan (IMP3) 2006-2020, to coincide with the country's vision for 2020 (MITI, 2005). Many policies regarding the Small and Medium-Sizes Enterprises have been implemented by Malaysian Government such as provision for financial access (Ali \& Nelson, 2006). It is clearly formulated to improve the growth in the manufacturing sectors.

Generally, Small and Medium-Sizes Enterprises can be started at a very low cost and on a part time basis which makes it suited to many economic activities. It also led to owner satisfaction in making their own decision within the constraints imposed by economic and other environmental factors even though they had to work very long hours (Longnecker, et al., 2008). This factor never made the Small and Medium-Sizes Enterprises non-popular among new businessmen in this country. It has helped them to improve their quality of life.

In Sabah, the development of this so-called Small and Medium-Sized Enterprises are very slow as compared to other states in Malaysia. This can be proved due to the low number of Small and Medium-Sized Enterprises being established in this state. Nowadays, the total population of over 3 million and as one of the largest state, we were really sure that this state would be capable of generating a large number of Small and Medium-Sized Enterprises. However, Bernama (March $16^{\text {th }}, 2011$ ) reported that there is only 24,794 Small and Medium-Sized Enterprises companies in Sabah which took the $10^{\text {th }}$ position in terms of the number of Small and Medium-Sized companies from the list of the 14 states in Malaysia.

However Lee (2006) stated that Sabah Small and Medium-Sized Enterprises as well as other Small and Medium-Sized Enterprises in Malaysia are being pushed into the forefront to face up with intense competition from large organizations and multinational corporations driven by globalization. Lee (2006) also stated that in order to compete in the K-economy, Sabah Small and Medium-Sized Enterprises have little option but to improve their competitiveness. This competitiveness improvement effort can only take place through increased funding by the local government.

Thus, the provision of financial assistance for Small and Medium-Sizes Enterprises in Malaysia is an important move undertaken by the government. It has been a remarkable effort to enhance the SMEs competitive level in this modern business world. It also has been a noble activity for the nation in order to make the people live decently. 


\section{Objectives}

The objective of this investigation is to examine the roles of government funding towards the competitiveness level of Small and Medium-Sized Enterprises in Sabah, Malaysia. Specifically, this study aimed to find out the roles of government's funding in enhancing the competitiveness of Small and Medium-Sized Enterprise which were located in neither urban nor the rural areas of Sabah, Malaysia.

\section{Methodology}

This study was carried out to investigate the main roles of government funding to enhance the competitiveness of Small and Medium-Sized Enterprises in Sabah, Malaysia. The information or data for this qualitative research were gathered through library research and field investigation as well as gathered data through personal investigation and secondary data interpretation. The information gathered through personal investigation was interpreted by the researchers and supported by opinions or even suggestions by other recent research. Specifically, the methodology of this study is presented as follows:

\subsection{Data Source}

Data was obtained from the (i) library research, and (ii) field investigation. For convenience, we refer to these two sources of the roles of government funding in enhancing the competitiveness of Small and Medium-Sized Enterprise in Malaysia, respectively. Library research involved the act of gathering data or information on the topics through reviews and understanding the related information. Therefore, in field investigations, data was gathered through direct observation on the competitiveness level of government's funded SMEs in Sabah, Malaysia.

\subsection{Calculation of the Improvement in Small and Medium-sizes Enterprises Competitiveness}

The effect of government funds was examined either by individual interpretation or collective interpretation of the researchers. In order to conclude either the government funds have positive effects on the level of Small and Medium-Sizes Enterprises competitiveness or otherwise, the provision of access to capital for opening and improving the business, provision of access to capital for skills and knowledge development, improvement of entrepreneurs relations, and promoting entrepreneurship and reducing "fears of failure" were evaluated.

\section{Findings}

Small and Medium-Sized Enterprises in Sabah, Malaysia were in general funded by many government-linked agencies such as Yayasan Tekun Nasional, Amanah Ikhtiar, Koperasi Pembangunan Desa and Agro Bank. The government funds which are normally awarded to local entrepreneurs would lead to the enhancement in its competitiveness level. Thus, this type of SMEs entrepreneurs gradually escape from poverty. In accordance, in this study, several main roles of government funding to enhance the competitiveness of Small and Medium-Sized Enterprises in Sabah, Malaysia were found. All these roles have been categorized into four main roles namely provision of access to capital for opening and improve the business, provision of access to capital for skills and knowledge development, improvement of entrepreneurs relations, and promoting entrepreneurship and reducing "fears of failure".

\subsection{Provision of Access to Capital for Opening and Improving the Business}

Primarily, this study found that the government funding is likely to improve SMEs competitiveness level through the provision of access to capital for opening and improving the business. Specifically, provision of access to capital for opening and improving the business among the Small and Medium-Sizes Enterprises is an important landmark to gear the Small and Medium-Sizes Enterprises into a higher step of competitive level. The governments efforts which is specifically concerned with business capital provision is supportive of the Small and Medium-Size Enterprises competitive level improvement in nature and will be continuously needed.

In this perspective, Marsh \& Runsten (1995) believe that input (business capital) can be expensive to many. However, Ali \& Nelson (2008) believe that the provision of capital for any activity (especially a provision of capital to the Small and Medium-Sized Enterprises) can be the major effort to create success in Small and Medium-Sized Enterprises. If financial as well as capital inputs are available many more Small and Medium-Sized Enterprises can be established by our people. In addition, if there is no access to capital then the entrepreneurs need much money to start their business and may be exposed to more risky sources of finance. Financial aid and business capital are important for starting Small and Medium-Sized Enterprises and improving their competitiveness level. According to Sarma, and Gandhi (1990) the availability of the financial assistance will improve any business activity. This means that the provision of capital assistantship by the Malaysian government especially among the Small and Medium-Sized Entrepreneurs in Sabah could enhance the Small and 


\section{Medium-Sizes Enterprises level of competitiveness.}

It is because of the lack of access to capital to funds that many Small and Medium-Sized Enterprises fail to get off the ground and prevail in competition. In contrast, if there are the government funds can give a boost to the Small and Medium-Sized Enterprises. If the entrepreneurs have easy access to financial capital then we really sure that the entrepreneurs would be able to operate their Small and Medium-Sized Enterprises in a very competitive level and there would also be able to compete with other economic activities in a similar sector.

Hence, provision of access to the capitol for opening businesses would bring about improvement in the competitiveness level of the Small and Medium-Sized Enterprises in Sabah, Malaysia and we would be able to see more small and medium scale industries.

\subsection{Provision of Access to Capital for Skills and Knowledge Development}

The researchers also discovered that one of the main roles of government funds in order to make Small and Medium-Sized Enterprises in Sabah, Malaysia become more competitive is through the provision of access to capital for skills and knowledge development. Chester and Neelameghan (2006) in commenting the impact that skills and knowledge will have on the improvement of competitive level; stated that everyone needs knowledge and skills to effectively manage something including business activities.

Antweiler (1998) also stated that by having improved skills and knowledge, someone maybe able to deal with many aspects in their life. Similarly, Small and Medium-Sized Enterprises also benefit by having entrepreneurs who have good skills and knowledge. By owning the skills and knowledge, he may have highest possibility to make his business activities become much more competitive. In contrast, if one does not have appropriate skills and knowledge then he may not have the ability to make his business activities competitive enough especially in this modern business environments which require high level of skills and knowledge.

Accordingly, with the availability of funds to Small and Medium-Sized Enterprises in Sabah, Malaysia, we find that a combination of a financial source and skills and knowledge bring about much improvement. The local government has not only allocated big amounts of money for SMEs, but also required the Small and Medium-Sized Entrepreneurs to attend funded training. Hence, by attending this funded training, the Small and Medium-Sized Entrepreneurs may able to use their new skills and knowledge to run their business effectively and it will enhance their business competitive level.

In short, in this study, by providing financial assistantship to the Small and Medium-Sized Enterprises in Sabah, Malaysian local governments have helped improve the level of competitiveness among the Small and Medium-Sized Enterprises in Sabah, Malaysia. Moreover, the provision of access to the capitol for knowledge and skills improvement will significantly improve the Small and Medium-Sized Enterprises in Sabah, Malaysia which may later lead the state into better economic development.

Entrepreneurs' relations also found that the Small and Medium-Sizes Enterprises improved when there is the financial assistantship provided by the local government in Sabah, Malaysia. It has been a big challenge for entrepreneurs to maintain social relations as well as it is important for different stakeholders to come together, share experiences and also to discuss their challenges pertaining to the critical issues related to their activities. Besides, the study found that in many community development projects implemented in Sabah, Malaysia, which are externally motivated, its' participant relations depend to a large extent on the influence of the promoter of the project. In accordance, through the implementation and the operation of the projects, the promoter as well as a local government must able to make the participants more interested and have strong ties with with his colleagues. In this context, financial assistantship that has been given by the local government were implemented along with its aims to improve the participants relations so that it will further increase their competitiveness level and they are able to come together to find solutions for successful business agendas.

Craig, et. al. (2005), Parnadeau (2010) and Teng, et. al. (2011) in commenting on this issue stated that the strong ties between entrepreneurs will enhance competitiveness and generate systematic escalations on the market. It is because, that the business activities that is funded by a specific agency will have good interaction between its participants and it would lead to trust and confidence, this by far might improve performance and hence the effectiveness of Small and Medium-Sizes Enterprises.

Hence, we believe that the government's efforts to provide the financial assistantship to the Small and Medium-Sized Entrepreneurship will strengthen the competitiveness level. It can be a reality through the improvement in the participants (entrepreneurs) relations as it would generate the cohesiveness among them in order to compete in this modern business environment. Finally, the improvement of the SMEs competitiveness level would also contribute to the improvement in the effectiveness of government funding in addressing the 
poverty level in Sabah, Malaysia.

\subsection{Promoting Entrepreneurship and Reducing "Fear of Failure"}

Undoubtedly, financial assistantship by the government will likely promote entrepreneurship and reduce 'fear of failure' among its potential participants. This issue can be a reality as the financial assistantship will make the potential entrepreneurs motivated to do business and have less fear of failure due to the lack of money to service loans.

Reynolds (2007) stated that the entrepreneurship is an act of being an entrepreneur. In this aspect, the person who is an entrepreneur is normally involved in making decisions of his own business activities. This particular person also plays a greater role in creating job opportunities which is much needed by the nation. In a very normal life, entrepreneurs participate in producing things or even providing services to many due to their ability for entrepreneurship.

Therefore, 'fear of failure' as according to Thakkar (2009) and Steel (2007) will likely to have its impact on many aspects. Accordingly, in our personal investigation, we do believe that the 'fear of failure' phenomenon if not properly overcome will lead to the failure of one's business activities. 'Fear of failure' is one of the greatest fears that people have and it is closely related to a fear of rejection and failure. Therefore, people who are able to overcome their 'fear of failure' successfully will likely to be successful in life.

In Small and Medium-Sized Enterprises however, the fear of failure phenomenon must be overcome. If the fear is not overcome properly then the efforts to increase the number of Small and Medium-Sizes Enterprises in this state (Sabah) would never become reality. Moreover, the 'fear of failure' will also contribute to the decrease in the level of competitiveness in the modern business environment of Small and Medium-Sizes Enterprises.

There is available a number of methods to properly deal with the fear problem. One is through the availability of easy access of financial assistantship by the entrepreneurs. These funds must also be easily obtained and should not entail a very strict method of repayment. In other words, the financial assistance also needs to be very borrower friendly and of course this is the kind of financial assistantship being practiced by the local government in Sabah, Malaysia.

Hence, government funds will improve greatly the entrepreneurship among people and will reduce the "fear of failure" among them. This role of government funds towards the Small and Medium-Sized Enterprises competitive level needs to be maintained as it is a vital effort by the government to reduce the poverty profile across country. In other words, government funding efforts must be intensified in order to make the Small and Medium-Sized Enterprises more competitive.

\section{Recommendations}

Based on the findings, we believe that the financial assistantship by the government will greatly boost Small and Medium-Sized Enterprises competitiveness level. Besides, it is highly recommended that the government continuously adopt the efforts to provide financial assistantship to the Small and Medium-Sized Enterprises. Moreover, there are some suggestions that we want to propose in order to improve the financial assistantship currently practiced by the government:

1) The government should be very committed in providing the financial assistance to the Small and Medium-Sized Enterprises and be able to deliver this assistantship efficiently.

2) The government must establish a very good delivery system for this project or assistantship and it must be done through many channels (e.g. commercial banks).

3) If there is a kind of confusion among Small and Medium-Sized Entrepreneurs on many aspects about the financial support by the government, then it must be overcome specifically by the appropriate government agencies.

4) The government needs to increase the number of centres or agencies that offer consultancy and expert services to explain about the financial assistantship.

5) The government must allocate the funds under its major development plans in order to make this effort meet its aims effectively.

6) The government must make the financial assistantship more easily accessible to people and make less strict the policies of the present financial assistantships. 


\section{Future Research}

Undoubtedly, this study has given an overview of the preliminary analysis on the roles of government funding in order to enhance the Small and Medium-Sized Enterprises competitive level in this modern world. However it does not completely reflect the empirical study of Small and Medium-Sized Entrepreneurs profiles in a very specific manner in Sabah, Malaysia. In accordance with the limitations of this study, we suggest that future research must be carried out in a very specific study on the Small and Medium-Sized Enterprises profiles in Sabah. The systematic study on how the Small and Medium-Sized Enterprises development can be boosted in ways other than the provision of funds by the government should also be studied.

Moreover, a future studies on the importance of the psychological aspects in enhancing the competitive level of Small and Medium-Sized Enterprises also needs to be carried out. We need to find out what are the psychological aspects that may contribute directly to the enhancement of the competitive levels of Small and Medium-Sized Entrepreneurs in Sabah. It must be carried out because Mohd. Zulkifli et al (2010) has stated that the Small and Medium-Sized Enterprises in Malaysia, especially in Sabah must take steps to improve their efforts to compete in this modern business world. Otherwise, Small and Medium-Sized Enterprises in this country may not be successful in eradicating poverty profiles in this country through more job creations.

\section{Conclusion}

So, overall, this study found that the government funds is much needed by the Small and Medium-Sized Enterprises in this state (Sabah) as it will be the main impetus for change in the level of competitiveness for Small and Medium-Sized Enterprises. This findings made us aware that SMEs must be funded by many parties such as government agencies and private sectors for them to improve their level of competitiveness. Chirot (1994) for example has stated that the institutional support will act as an impetus to jump start the Small and Medium-Sizes Enterprises to be more competitive.

Moreover, in short, government must continuously provide substantial funds to the local enterprises as well as the Small and Medium-Sized Enterprises. In many cases, government funds are the only 'hope' to anyone who aspires to be involved in Small and Medium-Sized Enterprises. Moreover, increase in government funding has the capability to improve Small and Medium Sized Enterprises competitive level especially in the global business environment as explained by Mohd. Zulkifli et. al. (2010).

\section{References}

Ali, S. S., \& Nelson, O. N. (2006). An Evaluation of SMEs Development in Malaysia. International Review of Business Research Papers, 2(1), 1-14.

Antweiler, C. (1998). Local knowledge and local knowing: an anthropological analysis of contested "cultural products" in the context of development. Anthropos, 93(4-6), 46-94.

Bernama. (2011, March 16). Sabah's SME development not as fast as other states. Retrieved from http://my.news.yahoo.com

Chester, G., \& Neelameghan, A. (2006). Information Professional: Knowledge and Skills Development for Serving Marginalized and Rural Communities. Webology, 3(3).

Chirot, D. (1994). How Societies Change. California: Pine Forge Press.

Craig, B. R., Jackson, W. E., \& Thomson, J. N. (2005). The role of Relationships in Small-Business Lending. Federal Reserve Bank of Cleveland.

Lee, D. T. M. (2006). Key Determinants of Knowledge Sharing (KS) and the Buliding of Competitiveness in Small and Medium Sized Enterprises in Sabah, Malaysia: A case Study. Theses of Professional Doctorate--Doctor of Business Administration (DBA). Faculty of Business and Law, University of Newcastle.

Longenecker, J. G., Carlos W. M., William, P., \& Leslie E. P. (2008). Small business management: launching and growing entrepreneurial ventures (14th ed.).

Ministry of International Trade and industry (MITI). (2005). The Third Industrial Master Plan (IMP3). Kuala Lumpur, Malaysia.

Mohd. Zulkifli, M., Abd Kamal, C., Mohd. Rushdan, Y., \& Zakiah, H. (2010). Small and Medium-Sized Entreprises (SMEs) Competing in the Global Business Environments: A Case of Malaysia. International Business Research, 3(1), 66-75.

Parnadeau, M. (2010). Speculative expectations and financial instabilities: when the competitive environment 
matters. Emerald Group Publishing Limited.

Reynolds, P. D. (2007). Entrepreneurship in the United States. USA: Springer.

SMIDEC. (2002). SMI Development Plan (2001-2005). Percetakan Nasional Malaysia Berhad, Kuala Lumpur.

SMIDEC. (2004). SME Performance 2003, Report. Kula Lumpur, Malaysia.

Steel, P. (2007). The Nature of Procrastination: A Meta-Analytic and Theoretical Review of Quintessential Self-Regulatory Failure. Psychological Bulletin, 133(1), 65-94. Retrieved December 11, 2008, from Academic Search Complete database. http://dx.doi.org/10.1037/0033-2909.133.1.65

Teng, H. S. S., Bhatia, G. S., \& Anwar, S. (2011). A success versus failure prediction model for small businesses in Singapore. An American Journal of Business, 26(1), 50-64. http://dx.doi.org/10.1108/19355181111124106

Thakkar, N. (2009). Why Procrastinate: An Investigation of the Root Causes behind Procrastination. Lethbridge Undergraduate Research Journal, 4(2).

Yaakub, J. (1991). Issues and Strategies in Rural Development Planning. Kota Kinabalu: Institute for Development Studies. 